\title{
Functional response and life history parameters of Apanteles taragamae, a larval parasitoid of Maruca vitrata
}

\author{
Elie A. Dannon · Manuele Tamò $\cdot$ Arnold van Huis $\cdot$ Marcel Dicke
}

Received: 14 August 2009/Accepted: 18 December 2009/Published online: 22 January 2010

(C) The Author(s) 2010. This article is published with open access at Springerlink.com

\begin{abstract}
The legume pod borer Maruca vitrata Fabricius (Lepidoptera: Crambidae) is a serious pest of cowpea in West-Africa. The parasitoid Apanteles taragamae Viereck (Hymenoptera: Braconidae) that originates from Taiwan is a potential candidate for biological control of $M$. vitrata. We investigated under laboratory conditions the functional response of the parasitoid by offering each experienced female 10, 20, 30 and 40 larvae of $M$. vitrata. We studied the influence of different host larval ages on the development, longevity, sex ratio, lifetime fecundity and parasitization rate of the wasp. In a comparative study, we also investigated the life history of A. taragamae and $M$. vitrata at different temperatures in the range of $20-30^{\circ} \mathrm{C}$. The parasitoid successfully parasitized two- and three-day-old host larvae (first and second instars). Younger larvae (one-day-old) were parasitized to a lesser extent, and only males
\end{abstract}

Handling Editor: Dirk Babendreier.

E. A. Dannon

Faculté des Sciences Agronomiques,

Université d'Abomey-Calavi, 01 BP 526 Cotonou, Benin

M. Tamò

International Institute of Tropical Agriculture (IITA),

Benin Station, 08 BP 0932 Cotonou, Benin

A. van Huis - M. Dicke ( $₫)$

Laboratory of Entomology, Wageningen University, P.O. Box 8031, 6700EH Wageningen, The Netherlands

e-mail: marcel.dicke@wur.nl developed in them. Older larvae were not parasitized, partly because of defensive host behaviour. The success of parasitization was positively correlated with the density of two-day-old $M$. vitrata larvae. Parasitoid developmental time and longevity decreased with increasing temperature. The intrinsic rate of population increase $\left(r_{m}\right)$ exhibited an optimum curve with a maximum at $24-28^{\circ} \mathrm{C}$. For the host M. vitrata, $r_{m}$ was maximal at temperatures of $26-30^{\circ} \mathrm{C}$. The data are discussed in the context of the potential of A. taragamae for biological control of M. vitrata.

Keywords Functional response .

Host age - Temperature - Apanteles taragamae . Maruca vitrata $\cdot$ Life history parameters

\section{Introduction}

Maruca vitrata Fabricius (Lepidoptera, Crambidae) is one of the key insect pests of cowpea, causing up to $80 \%$ of yield loss (Nampala et al. 2002). It originates from the Indo-Malaysian region and is a key pest of grain legumes in the tropics and subtropics (Tamò et al. 1997; Taylor 1978). The crambid develops without diapause and relies on alternate host plants to maintain its population during the cowpea off-season (Arodokoun et al. 2003; Bottenberg et al. 1997; Taylor 1978). 
Control of $M$. vitrata in cowpea has mainly been achieved by using synthetic insecticides (Sharma 1998; Kamara et al. 2007). Besides chemical control, cultural practices and moderately resistant varieties have been developed (Kamara et al. 2007). However, cultural practices and improved varieties still require supplemental applications of synthetic pesticides in order to obtain a substantial yield increase (Sharma 1998). This situation often results in an overuse of chemicals with side effects such as pest resurgence and secondary pest outbreaks, insecticide resistance, environmental pollution, and increased human health risks (Ekesi 1999). Therefore, it appears important to investigate other, environmentally benign control methods that can regulate the populations of the legume pod borer. Of these, classical biological control remains an attractive option, in particular after Apanteles taragamae Viereck, a solitary endoparasitoid, was recorded attacking $M$. vitrata larvae (Huang et al. 2003).

The wasp was reported parasitizing only $M$. vitrata in Taiwan. However, some reports about this wasp species indicated that it was gregarious and that it parasitized five other Pyraloidea species in India (Peter and David 1990; Mohan and Sathiamma 2007). For that reason, we believe that the latter wasp species is likely to be different from the one we have received from Taiwan, which is strictly solitary (Huang et al. 2003). The parasitoid was imported from Taiwan to the International Institute of Tropical Agriculture (IITA) in Benin for assessing its potential as a biocontrol agent against $M$. vitrata. In fact, prior to large scale field releases of any biocontrol agent, key aspects of its biology and ecology should be understood or evaluated (van Lenteren et al. 2003). Life history parameters provide useful information on the efficiency of biological control agents, particularly when comparing them with the ones of the target pest. Development, reproduction and survival of parasitoid insects are life history components that depend on physiological and environmental factors (Harbison et al. 2001; Uçkan and Ergin 2003). These factors can be either abiotic (e.g. temperature, relative humidity) or biotic (e.g. size, age, and density of the host).

The nutritional quality of an insect host is found to be correlated with its body size (West et al. 1999; Thorne et al. 2006), as large hosts contain more resources (Uçkan and Ergin 2002). Thus, the host size selected for oviposition by a female parasitoid affects the size and sex of its progeny (Arthur and Wylie 1959; Jones 1982; King 1987; Dicke 1999; Lacoume et al. 2006). In general, large adult parasitoids emerge from large hosts, and a larger proportion of females are produced when larger hosts are selected by the female parasitoid (Dicke 1999). In addition, large parasitoid females were found to have more eggs immediately available upon emergence, or to be able to generate them when needed, and have longer life expectancy than small females (Cloutier et al. 2000). However, the influence of host size on koinobiont parasitoids is complex (Harvey 2005). Larval development of koinobiont parasitoids such as A. taragamae after parasitization relies on the growth rate of the host (Brodeur and Boivin 2004; Harvey 2005; Pennacchio and Strand 2006). The host stage selected for oviposition by a koinobiont female is primarily based on the first host evaluation (Jones 1982; Brodeur and Boivin 2004). There is a host size (larval instar) threshold below which the female parasitoid rejects the host for parasitization (Jones 1982; Brodeur and Boivin 2004). Large hosts can exhibit strong defensive behaviour, and this can interfere with the possibility of parasitization (Brodeur et al. 1998).

Host density is reported to affect the performance of a parasitoid (Uçkan et al. 2004). The functional response of a parasitoid can be inversely or positively host-density dependent, or independent from host density (Holling 1959). The type of functional response is another essential factor in the selection of efficient biological control agents. How a parasitoid responds to an increasing host population can determine the success of biological control.

Abiotic factors such as temperature and relative humidity influence the life history parameters and the performance of biological control agents. In classical biological control, environmental adaptability of introduced parasitoids is one of the key factors that determine their establishment and effectiveness (Kalyebi et al. 2006). There is a strong influence of temperature on developmental rate, survival, and fecundity of parasitoids (Taylor 1981; Roy et al. 2002; Kontodimas et al. 2004; Kalyebi et al. 2006). The relationship between temperature and developmental rate has been described as negative and linear over most of the temperature range (Campbell et al. 1974). Typically, development ceases below a lower 
thermal threshold. Above it, the rate of development increases with temperature until an optimum is reached. Above the optimal temperature, the rate rapidly decreases to zero (Campbell et al. 1974; Brière et al. 1999).

The effect of environmental factors on the biological characteristics of $A$. taragamae has never been studied using its host $M$. vitrata. In the present study, we investigated the effect of host larval age on biological parameters of A. taragamae, such as development time from egg to adult, longevity, fecundity, sex ratio, and parasitization rate. We studied the functional response of the wasp, and the effect of temperature on life history parameters of A. taragamae and of its host $M$. vitrata. We also tested different models describing the relationship between temperature and the intrinsic rate of natural increase.

\section{Materials and methods}

Mass rearing of $M$. vitrata

Pupae of $M$. vitrata were obtained from a stock culture at the field station of the International Institute of Tropical Agriculture (IITA) in Benin. They were placed in open Petri dishes that were incubated in wooden cages $(44 \mathrm{~cm} \times 45 \mathrm{~cm} \times 58 \mathrm{~cm})$ with sleeves, having sides of fine screen and a glass top, and kept at $27.0 \pm 0.6^{\circ} \mathrm{C}$ and $60.9 \pm 4.6 \%$ relative humidity (mean $\pm \mathrm{SD}$ ). Adults emerged inside the cages and were nourished using cotton fibers moistened with $10 \%$ glucose solution. Four-day-old female moths were transferred in groups of four or five individuals in transparent small plastic cups $(3 \mathrm{~cm}$ diameter $\times 3.5 \mathrm{~cm}$ height) and kept for $24 \mathrm{~h}$ to allow oviposition, which occurred on the inner surface of the cups. Ovipositing females were fed using small pieces of filter paper moistened with $10 \%$ glucose solution, which were replaced after $24 \mathrm{~h}$. Cups carrying eggs were kept at the same experimental conditions till the larvae hatched. Larvae were transferred to cylindrical plastic containers $(9 \mathrm{~cm}$ diameter $\times 12 \mathrm{~cm}$ height) provided with artificial diet prepared according to Jackai and Raulston (1988), and reared until pupation. Larvae develop through five instars. Pupae were collected and placed in cages. All larvae used in the experiments were obtained from the mass production.
Mass rearing of A. taragamae

Cocoons of A. taragamae were obtained from the stock culture at IITA station in Benin, originally collected from the widely cultivated green manure crops Sesbania cannabina (Retz) Pers. infested by M. vitrata at the World Vegetable Center (AVRDC) in Taiwan. Emerged adults were kept in cylindrical plastic cups ( $4.5 \mathrm{~cm}$ diameter $\times 5 \mathrm{~cm}$ height). A hole ( $2 \mathrm{~cm}$ diameter) punched in the lid of the cups was covered with fine mesh. Adults of A. taragamae were fed with honey streaked on the fine mesh of the lid. To allow mated female wasps to parasitize hosts, they were offered, during $24 \mathrm{~h}$, two-day-old larvae of $M$. vitrata in a small cylindrical cup $(3 \mathrm{~cm}$ diameter $\times 3.5 \mathrm{~cm}$ height) containing a piece of artificial diet. The exposed larvae were reared till cocoon stage. Cocoons were collected and placed in cups ( $4.5 \mathrm{~cm}$ diameter $\times 5 \mathrm{~cm}$ height). The mass production of wasps took place in a climate chamber with a temperature of $25.3 \pm 0.5^{\circ} \mathrm{C}$ and a relative humidity of $78.9 \pm 5.6 \%$ (mean $\pm \mathrm{SD}$ ).

Influence of larval age of $M$. vitrata on development time, longevity, fecundity and sex ratio of $A$. taragamae

The influence of larval age of $M$. vitrata hosts on different biological parameters of A. taragamae was studied using three-day-old couples (male/female) of the wasp. Mating of a $24 \mathrm{~h}$-old parasitoid female was allowed for $48 \mathrm{~h}$ by introducing a male of the same age in a small cup. This experiment was conducted in two steps. A preliminary explorative experiment was designed to assess the range of larval ages suitable to A. taragamae parasitization. A $M$. vitrata larva of 1 , $2,3,4,5,6,7,8,9$ or 10 days age was exposed to one naïve (i.e. without oviposition experience) mated female for parasitization. Parasitization was monitored visually. This was done twice using different females. In parallel to this experiment, a second preliminary experiment has been conducted. Here, ten larvae of each of the ten ages were separately placed in small cups $(3 \mathrm{~cm}$ diameter $\times 3.5 \mathrm{~cm}$ height) containing artificial diet, and one mated female parasitoid was released in each cup for $24 \mathrm{~h}$ to allow parasitization. Subsequently, the larvae were reared on artificial diet till cocoon stage. 
In another experiment, 100 larvae each of either one, two or three-day-old were offered to female wasps for parasitization, 25 of each age per day during four consecutive days. Larvae of the three ages were exposed to the female wasps in different sequences to limit the effect of female physiology. Thus, a female was allowed to oviposit successively in five one-day-old larvae, five two-day-old larvae, and five three-day-old larvae. After that, the sequence 3, 2 and 1-day-old was used for a second parasitoid individual, then 2, 1, 3, then 2, 3, 1 and so on. Each female was allowed to parasitize at most five larvae of each age. Parasitized larvae of each age were reared individually in small cups containing artificial diet. Larval development and survival were examined daily. The number of successfully parasitized larvae was also recorded, as well as the development time from larval to cocoon stage and from cocoon stage till adult emergence. The parasitization rate was calculated for each age from the number of parasitoid cocoons resulting from 25 parasitized larvae. Adult females were kept for mating with males of the same age. Each couple of wasps was offered 20 to 30 twoday-old $M$. vitrata larvae daily until the female died. After being exposed to the parasitoid couple, the larvae were transferred individually into small cups containing artificial diet and reared until cocoon stage. We recorded the number of cocoons of A. taragamae as well as the number of adult male and female parasitoids that emerged. As our Taiwan strain of A. taragamae is a solitary parasitoid, only one individual emerged from a cocoon. Hence, the observed lifetime fecundity per female was determined in terms of number of cocoons. This study was carried out in a climate chamber under $25.3 \pm 0.5^{\circ} \mathrm{C}$ and $78.9 \pm 5.6 \%$ relative humidity (mean $\pm \mathrm{SD}$ ).

Effect of larval density of $M$. vitrata on the rate of parasitization by A. taragamae

In this experiment, $10,20,30$, or 40 two-day-old $M$. vitrata larvae, reared in small cups $(3 \mathrm{~cm}$ diameter $\times 3.5 \mathrm{~cm}$ height) containing artificial diet, were placed in cylindrical plastic containers $(9 \mathrm{~cm}$ diameter $\times 12 \mathrm{~cm}$ height). One three-day-old mated and oviposition-experienced female parasitoid (by parasitizing three two-day-old larvae, $10 \mathrm{~min}$ prior to the experiment) was placed for $24 \mathrm{~h}$ in each container. Each density was repeated five times using different female parasitoids, so a total of 20 experienced mated female wasps was used. In a preliminary experiment, holes ( $1 \mathrm{~cm}$ diameter) were made in the cover of the plastic containers in order for the parasitoids to be able to escape from the setup. This was done in order to allow the parasitoid either to oviposit or to escape. However, since all female wasps escaped during the first runs without parasitizing larvae, all further experiments were done without the hole in the container lid. After parasitoid exposure, larvae were transferred individually into small cups containing artificial diet and reared till cocoon stage. The number of parasitized larvae in terms of number of parasitoid cocoons for each density was recorded. This study was carried out in a climate chamber at $25.3 \pm 0.5^{\circ} \mathrm{C}$, and $78.9 \pm 5.6 \%$ relative humidity (mean $\pm \mathrm{SD}$ ).

Influence of larval age on the life history parameters of $A$. taragamae reared on $M$. vitrata

Three-day-old mated females of A. taragamae were introduced into small cups $(3 \mathrm{~cm}$ diameter $\times 3.5 \mathrm{~cm}$ height) containing about 20 two-day-old larvae of $M$. vitrata for parasitization. Parasitization was observed visually. Stung larvae were individually transferred to other small cups $(3 \mathrm{~cm}$ diameter $\times$ $3.5 \mathrm{~cm}$ height) and reared at one of five constant temperatures, i.e. $20,24,26,28$ or $30^{\circ} \mathrm{C}$ under a relative humidity range of $70-90 \%$ in incubators. Previous studies had shown that the range of temperatures for successful development of $M$. vitrata is between $19.5^{\circ} \mathrm{C}$ and $31.9^{\circ} \mathrm{C}$ (Adati et al. 2004). The constant temperatures tested in this study cover most of the ranges occurring in Benin ecosystems (Emert and Brücher 2008). The temperature regimes are also required to estimate accurately the thermal requirements for insect development and survival using the models described below (Campbell et al. 1974). Temperature and relative humidity were measured twice a day over the whole experimental period using a thermo-hygrometer placed inside the incubator. The realized five temperatures regimes were $20.2 \pm 0.6$, $24.2 \pm 0.4, \quad 26.1 \pm 0.6, \quad 28.2 \pm 0.8$ and $29.6 \pm$ $0.3^{\circ} \mathrm{C}$, and the relative humidity for each of these temperatures were $79.3 \pm 11.8,73.2 \pm 10.5,88.2 \pm$ $7.2,68.2 \pm 10.7$ and $78.2 \pm 10.6 \%$ (mean $\pm \mathrm{SD}$ ), respectively. A total of 100-150 larvae were reared on artificial diet under each temperature regime. Larval survival was checked daily until cocoon stage and the 
number of cocoons from which adult wasps emerged was recorded. Development time was recorded for two developmental phases (larva-cocoon and cocoonadult) and the sex of the emerged adult was also determined. Each female was coupled with a male of the same age in small cups. A drop of honey solution was put onto the cover of each cup to allow the adults to feed. Each couple of wasps received daily 20-30 two-day-old larvae of $M$. vitrata until the female died. A total of 30 pairs of wasps were used per temperature regime. Larvae were reared on artificial diet until cocoon formation. The number of cocoons, emerged adults and their sex ratio were recorded for each female. Realized lifetime fecundity of females was then recorded in terms of the number of cocoons. In parallel, 100-150 two-day-old non-parasitized larvae of $M$. vitrata taken from the same larval population were reared at each temperature as control.

Life table parameters were calculated for A. taragamae and for its host M. vitrata. They are defined according to Birch (1948):

- The net reproductive rate $R_{0}$, which is the number of female progeny per female per generation. It is given by the following formula:

$R_{o}=\sum l_{x} m_{x}$

where: $x$ is the pivotal age of individuals in days, $l_{x}$ is the age-specific survival as proportion of individuals still alive at age $x, m_{x}$ is the age-specific fecundity as female offspring per female.

- The intrinsic rate of increase $r_{m}$, given by the formula:

$1=\sum l_{x} m_{x} e^{-r_{m} x}$

where $e$ is the base of natural logarithm (ln).

- The mean generation time $T$, calculated as follows: $T=\ln \left(R_{0}\right) / r_{m}$ and by approximation $T=\left(\sum x l_{x} m_{x}\right) / \sum l_{x} m_{x}$

- The doubling time $T_{2}$ is therefore:

$T_{2}=\ln (2) / r_{m}$

- The finite rate of increase $\lambda$, expressed as the multiplication per female per unit time:

$\lambda=e^{r_{m}}$

The intrinsic rate of increase $r_{m}$ was calculated using the Jackknife technique (Maia et al. 2000). All these life table parameters were computed using the SAS program developed by Maia et al. (2000). This program includes multiple comparisons between groups and does not assume the same immature stage survivorship for all groups as done with the computer program developed by Hulting et al. (1990).

The effect of temperature on the intrinsic rate of increase $\left(r_{m}\right)$ and the developmental rate $\left(d^{-1}\right)$ of A. taragamae and of its host $M$. vitrata was examined using mathematic models. The developmental rate is the reciprocal $\left(d^{-1}\right)$ of the development time $(d)$ (Howe 1967). Several models have been elaborated to describe the relationships between temperature and the intrinsic rate of increase or the developmental rate of insect species (Campbell et al. 1974; Brière et al. 1999; Roy et al. 2002). Of these, we selected the linear and Brière 1 models to describe the relationship between temperature and developmental rate or intrinsic rate of increase of $A$. taragamae and of its host $M$. vitrata. Equations of these models are as follows:

Linear model: $r_{m}=a+b T$ where $r_{m}$ is the intrinsic rate of increase, $a$ and $b$ are regression coefficients, $T$ is the temperature in ${ }^{\circ} \mathrm{C}$.

Brière 1: $r_{m}=a T\left(T-T_{o}\right)\left(T_{\max }-T\right)^{1 / 2}$ where $r_{m}$ is the intrinsic rate of increase, $T_{0}$ is the lower temperature threshold, $T_{\max }$ is the upper temperature threshold, $a$ is an empirical constant.

The same models have been used to describe the relationship between the temperature and the developmental rate $(d)$ of $A$. taragamae and of its host $M$. vitrata. Equations of the models become:

Linear model: $1 / d=a+b T$

Brière $1: 1 / d=a T\left(T-T_{o}\right)\left(T_{\max }-T\right)^{1 / 2}$ where $d$ is the mean development time from egg to adult, models parameters are defined as above.

Thus, in the model equations, both $r_{m}$ and $d^{-1}$ were used, where $d$ is the mean development time from egg to adult for both insect species. Brière 1 model allowed determining the lower and upper thermal thresholds for each insect species (Brière et al. 1999). We were interested in describing the relationship between temperature and the two parameters $r_{m}$ and $d^{-1}$ which have different ecological meanings. The intrinsic rate of natural increase $r_{m}$ (measured in terms of number of female offspring/ female/day) refers to population increase (Birch 1948), while the development rate refers to individual development rate (Howe 1967). The linear model 
used for describing the developmental rate enables the calculation of the thermal constant $K$, a kind of physiological time defined as the amount of heat units required for development. $K$ is the inverse of the regression coefficient $b$ of the linear model $(K=1 / b)$.

The coefficients of the linear model were computed using the linear regression procedure, while the different parameters in the Brière 1 model were computed with the nonlinear regression procedure with the Levenberg-Marquardt iterative method (Marquardt 1963).

\section{Statistical analysis}

The effect of larval host age on the duration of each parasitoid stage (larval, cocoon or pupae, adult), of the whole cycle, of the male or female cycle, and on female fecundity was tested by using the GLM procedure of SAS followed by the Tukey test for the separation of means. Comparison between male and female longevity was done with a paired $t$-test. Likewise, the influence of temperature on the different biological parameters, development time of each stage, longevity, fecundity, immature survivorship rate, intrinsic rate of increase, net reproduction rate, mean time generation, doubling time and the finite rate of increase have been compared by performing ANOVA using the GLM procedure of SAS followed by the Tukey-test for the separation of the means. Data on sex ratio (female proportion) were analyzed by using the $\chi^{2}$ test. Thus, a $2 \times 2$ contingency table based on the $\chi^{2}$ was used to test for between-larval age differences, while a $2 \times 5$ contingency table was used to test for between-temperatures differences in sex ratio. Comparison of development cycle and longevity between male and female were done with a paired $t$-test. Percentage data such as proportions of parasitized larvae and proportions of immature parasitoid stages survivorship were arcsine-square root transformed prior to analysis. Proportion of immature parasitoid stages is the proportion of parasitized larvae that successfully completed the cycle and gave adults. However, untransformed data were presented in tables. Simple linear regression was applied to determine the relationship between larval density and proportion of parasitized larvae. The $t$-test was used to compare the intrinsic rate of increase of the parasitoid and of its host.

\section{Results}

Influence of larval host age on some biological parameters of Apanteles taragamae

Of the ten larval age groups (one-ten-day-old larvae) tested only larvae of one-, two- and three-day-old were successfully parasitized by A. taragamae, while older larvae escaped parasitism. Visual observation indicated that the female wasps were not able to immobilize larvae older than three days, which consequently escaped oviposition. The development time of immature stages (larvae and cocoon) of A. taragamae was not significantly influenced by the age of $M$. vitrata larvae (Table 1). However, the whole development cycle of the parasitoid was about half a day and one day shorter, respectively, when two- and three-day-old larvae were parasitized compared to that of one-day-old parasitized larvae $(F=10.75 ; d f=2,44 ; P=0.001)$. The same effect was observed for males but not for females. Males that emerged from larvae which were parasitized at the age of one day, lived significantly longer than the males from larvae which were parasitized at the age of two or three days. No significant differences were observed between the longevity of male and female parasitoids when larvae of two- or three-day-old had been parasitized by their mothers.

The proportion of successfully parasitized larvae was significantly lower (about 50\%) for one-day-old larvae compared to two- or three-day-old larvae (Table 1). Only male wasps emerged from larvae that had been parasitized at the age of one day, while larvae parasitized when two- or three-day-old yielded both male and female wasps. No differences were observed between the fecundity of females whose mothers had parasitized two- or three-day-old larvae. The percentage of female offspring was significantly lower than the expected frequency of $50 \%$ when the parasitoids parasitized three-day-old larvae (Table 1). When comparing larval ages, there was a marginally insignificant $\left(\chi^{2}=2.9 ; d f=2 ; P=0.08\right.$ ) difference in the percentage of females obtained from two- to three-day-old parasitized larvae.

\section{Host density}

The percentage parasitism of $M$. vitrata larvae by A. taragamae increased with larval density 
Table 1 Influence of the age of $M$. vitrata larvae on the development time (mean $\pm \mathrm{SE}$ ), longevity, parasitization rate, fecundity and sex ratio of Apanteles taragamae

\begin{tabular}{|c|c|c|c|}
\hline \multirow[t]{2}{*}{ Parasitoid life-history parameters } & \multicolumn{3}{|c|}{ Maruca vitrata larval age at parasitization } \\
\hline & 1 Day & 2 Days & 3 Days \\
\hline \multicolumn{4}{|l|}{ Development time (days) } \\
\hline Egg-cocoon & $8.3 \pm 0.11(30) \mathrm{a}$ & $7.9 \pm 0.11(67) \mathrm{a}$ & $7.7 \pm 0.08(57) \mathrm{a}$ \\
\hline Cocoon-adult & $5.0 \pm 0.12(12) \mathrm{a}$ & $5.2 \pm 0.12(43) \mathrm{a}$ & $4.9 \pm 0.09(45) \mathrm{a}$ \\
\hline Egg-adult (cycle) & $13.6 \pm 0.23(12) \mathrm{a}$ & $12.9 \pm 0.14(43) \mathrm{b}$ & $12.5 \pm 0.13(45) \mathrm{c}$ \\
\hline \multicolumn{4}{|l|}{ Development cycle egg-adult (days) } \\
\hline Male & $13.6 \pm 0.23(12) \mathrm{a}$ & $12.8 \pm 0.16(25) \mathrm{b} \alpha$ & $12.2 \pm 0.11(32) \mathrm{c} \alpha$ \\
\hline Female & - & $13.1 \pm 0.25(18) \mathrm{a} \alpha$ & $13.2 \pm 0.30(13) \mathrm{a} \beta$ \\
\hline \multicolumn{4}{|l|}{ Longevity (days) } \\
\hline Male & $19.8 \pm 3.01(12) \mathrm{a}$ & $13.4 \pm 1.75(25) \mathrm{b} \alpha$ & $8.5 \pm 1.73(32) \mathrm{b} \alpha$ \\
\hline Female & - & $11.0 \pm 1.60(15) \mathrm{a} \alpha$ & $8.8 \pm 1.45(12) \mathrm{a} \alpha$ \\
\hline Survival rate of larvae and cocoons $(\%)$ & $7.0 \pm 3.0(4) \mathrm{a}$ & $43.0 \pm 8.5(4) b$ & $46.0 \pm 5.8(4) b$ \\
\hline Parasitization rate $(\%)$ & $35.0 \pm 7.9(4) \mathrm{a}$ & $67.0 \pm 2.5(4) b$ & $56.0 \pm 2.8(4) \mathrm{ab}$ \\
\hline Sex ratio ( $\%$ of females in the population) & 0.0 & 40.5 a. n.s. & $27.3 a^{*}$ \\
\hline Female fecundity (number of cocoons per female) & - & $55.5 \pm 5.6(14) \mathrm{a}$ & $42.2 \pm 8.1(11) \mathrm{a}$ \\
\hline
\end{tabular}

Numbers in parentheses are the number of repetitions. Each repetition consists of 25 host larvae

Means within each row followed by the same letters were not significantly different with Tukey test at 5\% following ANOVA for development times, longevity, survival rate and parasitization rate

For comparison between males and females, means within each column followed by Greek letters were not significantly different (paired $t$-test at $5 \%$ )

Sex ratios followed by the same letter were not significantly different with $\chi^{2}$ at $5 \%$ (based on $2 \times 2$ contingency tables) for comparison between the host larval ages of 2 versus 3 days

- Indicates that the parameter is not available because only male wasps emerged from one-day-old parasitized larvae

*Indicates that there was a difference $\left(P \leq 0.05, \chi^{2}\right)$, and n.s. no difference $\left(P>0.05, \chi^{2}\right)$, between the sex ratio from the expected percentage of $50 \%$, as assessed for each larval age separately

$\left(y=0.61 x+8.00 ; R^{2}=0.92 ; F=25.7 ; d f=1,2 ;\right.$ $P=0.03$ ) (Fig. 1). Thus, the wasps exhibited a host density-dependent functional response within the range of densities tested.

\section{Temperature}

The development time of A. taragamae from egg to cocoon, from cocoon to adult and from egg to adult decreased significantly with an increase in temperature from $20^{\circ} \mathrm{C}$ to $30^{\circ} \mathrm{C}$ (Table 2). The duration of the total life cycle from egg to adult was almost reduced by half when going from $20^{\circ} \mathrm{C}$ to $24^{\circ} \mathrm{C}$ (25-13 days), then it was reduced by another three days (10 days) at $28^{\circ} \mathrm{C}$ and $30^{\circ} \mathrm{C}$. The same effect was observed for the development cycle of male or female wasps. Comparison between male and female development

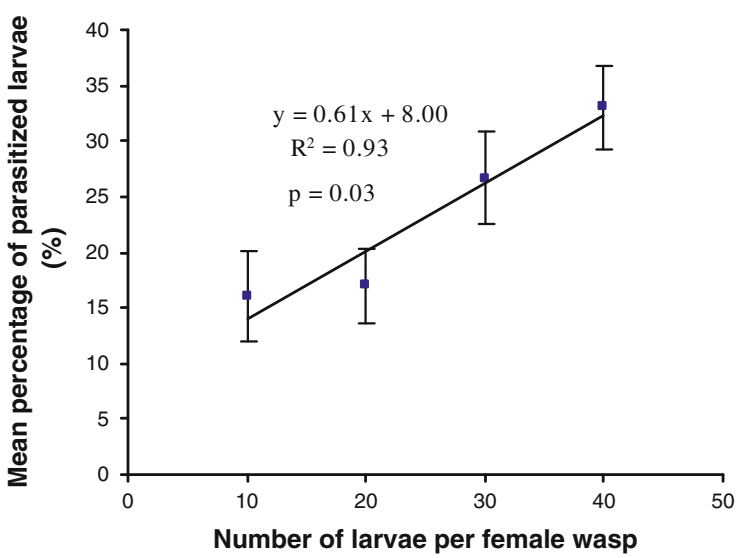

Fig. 1 Relationship between the larval densities of Maruca vitrata and the parasitization rate (mean $\pm \mathrm{SE}$ ) by Apanteles taragamae 
rates at the same temperature level revealed a significant difference at all temperatures except at $28^{\circ} \mathrm{C}$. The development cycle of males was significantly shorter than the cycle of females at 20, 24 and $26^{\circ} \mathrm{C}$, but longer at $20^{\circ} \mathrm{C}$ and $30^{\circ} \mathrm{C}$. The highest lifetime fecundity was obtained at $20^{\circ} \mathrm{C}(123 \pm 12.9$ cocoons per female), while the daily fecundity was lowest with $1.2 \pm 0.46$ cocoons per female per day at $30^{\circ} \mathrm{C}$ and highest with about seven between $24^{\circ} \mathrm{C}$ and $28^{\circ} \mathrm{C}$. The lowest survival rate of parasitoid larval and cocoon stages (about $70 \%$ ) was obtained at $20^{\circ} \mathrm{C}$ and $30^{\circ} \mathrm{C}$, and the highest at $24^{\circ} \mathrm{C}$ (about $80 \%$ ). The proportion of female wasps seemed not to be affected by the temperature $\left(\chi^{2}=0.19 ; d f=4 ; P=0.996\right)$ and was significantly lower than the expected proportion of $50 \%\left(\chi^{2}\right.$ were $28.3,33.3,30.7,29.5$ and 33.3 , respectively, at $20,24,26,28$ and $30^{\circ} \mathrm{C}$ with $d f=1$ and $P<0.0001$ for the five temperatures). Linear regression analysis revealed a significant negative correlation between the temperature and the following parameters: development time from egg to cocoon $\left(y=28.67-0.81 x ; R^{2}=\right.$ $0.87 ; F=20.8 ; d f=1,3 ; P=0.02)$, development time from cocoon to adult emergence $(y=23.57-$ $\left.0.69 x ; R^{2}=0.76 ; \quad F=9.9 ; d f=1,3 ; P=0.05\right)$, duration of the whole developmental cycle (from egg to adult) $\left(y=5.95-1.49 x ; R^{2}=0.83 ; F=14.4\right.$; $d f=1,3 ; P=0.03)$, development time for males $\left(y=49.53-1.41 x ; R^{2}=0.83 ; F=14.9 ; d f=1\right.$, $3 ; P=0.03)$ and females $\left(y=54.45-1.56 x ; R^{2}=\right.$ $0.83 ; F=14.03 ; d f=1,3 ; P=0.03)$, male longevity $\left(y=52.54-1.61 x ; \quad R^{2}=0.87 ; \quad F=19.96\right.$; $d f=1, \quad 3 ; \quad P=0.02), \quad$ female longevity $(y=$ $54.80-1.71 x ; \quad R^{2}=0.96 ; \quad F=74,4 ; \quad d f=1, \quad 3 ;$ $P=0.003)$ and the life time fecundity $(y=$ $341.13-10.87 x ; R^{2}=0.96 ; F=77.97 ; d f=3,1$; $P=0.003)$. There was no significant correlation between temperature and the daily fecundity $(F=1.07 ; d f=1,3 ; P=0.38)$ and the survival rate of parasitoid larvae and cocoons $(F=0.56$; $d f=1,3 ; P=0.51)$.

Development time of the different stages of $M$. vitrata followed the same tendency as in the case of A. taragamae (Table 3). The life cycle duration was reduced from 39 to 19 days by increasing temperatures from $20^{\circ} \mathrm{C}$ to $30^{\circ} \mathrm{C}$. Male moths lived significantly longer than females at $20^{\circ} \mathrm{C}$ and $30^{\circ} \mathrm{C}$. Linear regression analysis showed a significant negative correlation between the temperature and the following parameters: development time from egg to pupal stage $\left(y=39.48-0.99 x ; R^{2}=0.93 ; F=39.25 ; d f=1\right.$, 3; $P=0.008)$, development time from from pupa to adult emergence $\left(y=34.76-1.03 x ; R^{2}=0.91\right.$; $F=29.1 ; d f=1,3 ; P=0.012)$, the whole life cycle $\left(y=76.88-2.00 x ; R^{2}=0.92 ; F=33.9 ; d f=1,3\right.$; $P=0.0101)$, the cycle for males $(y=75.96-1.99 x$; $\left.R^{2}=0.88 ; \quad F=21.3 ; d f=1,3 ; P=0.019\right)$ and females $\left(y=77.36-2.03 x ; R^{2}=0.92 ; F=35.65\right.$; $d f=1,3 ; P=0.009)$, male longevity $(y=50.44$ $-1.47 x ; \quad R^{2}=0.91 ; \quad F=29.76 ; \quad d f=1,3 ; \quad P=$ $0.012)$, female longevity $\left(y=39.25-1.07 x ; R^{2}=\right.$ $0.91 ; F=30.8 ; d f=1,3 ; P=0.011)$ and the immature stages survival rate $(y=123.01-1.19 x$; $\left.R^{2}=0.89 ; \quad F=24.5 ; \quad d f=1,3 ; P=0.016\right)$. No significant correlation was observed between the temperature and the life time fecundity $(F=0.17$; $d f=1,3 ; P=0.70)$ and the daily fecundity $(F=0.1$; $d f=1,3 ; P=0.94)$ of $M$. vitrata. The observed lifetime fecundity reached a maximum value of $246 \pm 29$ eggs female ${ }^{-1}$ at $26^{\circ} \mathrm{C}$ and lower values of $122 \pm 17$ and $47 \pm 16$ eggs female ${ }^{-1}$, at $20^{\circ} \mathrm{C}$ and $30^{\circ} \mathrm{C}$, respectively. Likewise, the daily fecundity followed a similar trend. The survival rate of larvae and pupae was reduced from $83 \%$ at $20^{\circ} \mathrm{C}$ to $63 \%$ at $30^{\circ} \mathrm{C}$. Sex ratio was not affected by temperature $\left(\chi^{2}=0.12 ; d f=4 ; P=0.998\right)$ and no difference was obtained between proportion of females and males of M. vitrata $\left(\chi^{2}\right.$ were $0.65,0.85,1.6,1.0$, and 0.85 , respectively, at $20,24,26,28$ and $30^{\circ} \mathrm{C}$ with $d f=1$ and $P>0.05$ for the five temperatures) (Table 3 ).

The life table parameters of $A$. taragamae and its host $M$. vitrata are given in Table 4 . The intrinsic rate of increase $\left(r_{m}\right)$ and the finite rate of increase $(\lambda)$ of A. taragamae followed a parabolic trend with a maximum between $24^{\circ} \mathrm{C}$ and $28^{\circ} \mathrm{C}$. The net reproduction rate, the mean generation time and the doubling time of the parasitoid, however, declined with increasing temperature. The intrinsic rate of increase $\left(r_{m}\right)$ and the finite rate of increase $(\lambda)$ of $M$. vitrata also showed a parabolic trend with a maximum between $26^{\circ} \mathrm{C}$ and $30^{\circ} \mathrm{C}$. Likewise, the net reproduction rate showed a parabolic trend with a maximum at $26^{\circ} \mathrm{C}$ while the mean generation and doubling times decreased with the temperature.

The intrinsic rate of increase of A. taragamae was significantly larger than the intrinsic rate of increase of its host $M$. vitrata at all temperature regimes with exception to $30^{\circ} \mathrm{C}$ ( $t$ were $6.7,7.8,8.7,4.4$, and -7.8 , 
Table 2 Development time (mean \pm SE), longevity (mean \pm SE), lifetime fecundity (mean \pm SE), daily fecundity (mean \pm SE), immature stages survivorship (mean $\pm \mathrm{SE}$ ) and sex ratio of Apanteles taragamae at five different temperatures

\begin{tabular}{|c|c|c|c|c|c|}
\hline \multirow[t]{2}{*}{ Parameters } & \multicolumn{5}{|c|}{ Temperatures regimes } \\
\hline & $20^{\circ} \mathrm{C}$ & $24^{\circ} \mathrm{C}$ & $26^{\circ} \mathrm{C}$ & $28^{\circ} \mathrm{C}$ & $30^{\circ} \mathrm{C}$ \\
\hline \multicolumn{6}{|l|}{ Development time (days) } \\
\hline Egg-cocoon & $\begin{array}{l}13.7 \pm 0.09 \\
(90) \mathrm{a}\end{array}$ & $\begin{array}{l}7.9 \pm 0.03 \\
(105) \mathrm{b}\end{array}$ & $\begin{array}{l}6.9 \pm 0.05 \\
(113) \mathrm{c}\end{array}$ & $5.7 \pm 0.05(97) \mathrm{d}$ & $\begin{array}{l}5.7 \pm 0.04 \\
\quad(130) \mathrm{d}\end{array}$ \\
\hline Cocoon-adult & $\begin{array}{l}11.3 \pm 0.16 \\
(65) \mathrm{a}\end{array}$ & $4.8 \pm 0.09(74) b$ & $5.2 \pm 0.12(64) b$ & $4.4 \pm 0.11(61) b c$ & $3.9 \pm 0.11(70) \mathrm{c}$ \\
\hline Egg-adult (cycle) & $\begin{array}{l}24.9 \pm 0.24 \\
(65) \mathrm{a}\end{array}$ & $\begin{array}{l}12.6 \pm 0.10 \\
(74) \mathrm{b}\end{array}$ & $\begin{array}{l}12.0 \pm 0.12 \\
(64) \mathrm{c}\end{array}$ & $10.0 \pm 0.10(61) \mathrm{d}$ & $9.7 \pm 0.08(70) \mathrm{d}$ \\
\hline \multicolumn{6}{|l|}{ Development cycle (days) } \\
\hline Male & $\begin{array}{l}23.9 \pm 0.25 \\
\quad(34) \mathrm{a} \alpha\end{array}$ & $\begin{array}{l}12.3 \pm 0.10 \\
(36) \mathrm{b} \alpha\end{array}$ & $\begin{array}{l}11.9 \pm 0.13 \\
(50) \mathrm{b} \alpha\end{array}$ & $9.9 \pm 0.16(31) c \alpha$ & $\begin{array}{l}9.4 \pm 0.09 \\
\quad(40) \mathrm{c} \alpha\end{array}$ \\
\hline Female & $\begin{array}{l}26.0 \pm 0.32 \\
\quad(30) \mathrm{a} \beta\end{array}$ & $\begin{array}{l}13.0 \pm 0.15 \\
(37) \mathrm{b} \beta\end{array}$ & $\begin{array}{l}12.9 \pm 0.18 \\
(36) \mathrm{b} \beta\end{array}$ & $\begin{array}{l}10.03 \pm 0.12 \\
\quad(30) \mathrm{c} \alpha\end{array}$ & $\begin{array}{l}10.1 \pm 0.08 \\
(30) \mathrm{c} \beta\end{array}$ \\
\hline \multicolumn{6}{|l|}{ Longevity (days) } \\
\hline Male & $\begin{array}{l}18.3 \pm 0.69 \\
(30) \mathrm{a} \alpha\end{array}$ & $\begin{array}{l}15.6 \pm 2.3 \\
(30) \mathrm{a} \alpha\end{array}$ & $\begin{array}{l}13.8 \pm 1.8 \\
(30) \mathrm{a} \alpha\end{array}$ & $5.3 \pm 0.76(30) \mathrm{b} \alpha$ & $\begin{array}{l}3.1 \pm 0.45 \\
\quad(30) \mathrm{b} \alpha\end{array}$ \\
\hline Female & $\begin{array}{l}21.9 \pm 0.90 \\
(30) \mathrm{a} \alpha\end{array}$ & $\begin{array}{l}12.0 \pm 0.81 \\
\quad(30) \mathrm{b} \alpha\end{array}$ & $\begin{array}{l}9.2 \pm 0.55 \\
\quad(30) \mathrm{bc} \beta\end{array}$ & $\begin{array}{l}7.7 \pm 0.73 \\
\quad(30) \mathrm{bc} \beta\end{array}$ & $\begin{array}{l}4.1 \pm 0.44 \\
\quad(30) \mathrm{d} \alpha\end{array}$ \\
\hline $\begin{array}{l}\text { Lifetime fecundity (cocoons/ } \\
\text { female) }\end{array}$ & $\begin{array}{l}123.3 \pm 12.7 \\
(30) \mathrm{a}\end{array}$ & $73.2 \pm 5.8(30) b$ & $64.7 \pm 6.0(30) b$ & $46.7 \pm 4.1(30) \mathrm{b}$ & $5.9 \pm 1.9(30) \mathrm{c}$ \\
\hline $\begin{array}{l}\text { Daily fecundity (cocoons/female/ } \\
\text { day) }\end{array}$ & $5.5 \pm 0.37(30) \mathrm{a}$ & $7.1 \pm 0.80(30) \mathrm{a}$ & $6.9 \pm 0.51(30) a$ & $6.8 \pm 0.61(30) a$ & $1.2 \pm 0.46(30) b$ \\
\hline $\begin{array}{l}\text { Survival rate of larvae and cocoons } \\
(\%)\end{array}$ & $71.0 \pm 2.0(3) \mathrm{ac}$ & $81.7 \pm 1.45(3) b$ & $76.0 \pm 0.58(3) \mathrm{a}$ & $69.3 \pm 1.2(3) \mathrm{c}$ & $67.3 \pm 0.66(3) c$ \\
\hline Sex ratio (\% females progeny) & $34.7 a^{*}$ & $33.3 \mathrm{a}^{*}$ & $34.3 \mathrm{a}^{*}$ & $34.0 a^{*}$ & $33.3 \mathrm{a}^{*}$ \\
\hline
\end{tabular}

Numbers in parentheses are the number of repetitions

Means within each row followed by the same letters were not significantly different with Tukey test at 5\% following ANOVA

Means within each column followed by Greek letters were not significantly different $t$-paired test at $5 \%$ for comparison between male and female

For sex ratio, female proportions followed by the same letter were not significantly different with $\chi^{2}$ at $5 \%$ (based on $2 \times 5$ contingency table) for comparison between temperatures

*Indicates that there was difference $\left(P>0.05, \chi^{2}\right)$ between observed and expected $(50 \%)$ percentages of the females at the same temperature

respectively, at $20,24,26,28$ and $30^{\circ} \mathrm{C}$ with $d f=2$ and $P<0.05$ for the five temperatures).

The linear model was not significant for the intrinsic rate of increase of $A$. taragamae $(F=0.02 ; d f=1,3 ; P=0.9)$ and was not appropriate for describing the relationship between the intrinsic rate of increase of A. taragamae (Table 5). The thermal constant required for the development of A. taragamae was lower than that of M. vitrata.

The curves describing the relationship between the temperature and the intrinsic rate of increase or the developmental rate of $A$. taragamae and of its host $M$. vitrata are depicted in Fig. 2. The nonlinear model
Brière 1, allowed estimation of the thermal thresholds for the developmental rate of A. taragamae and of the intrinsic rate of increase of $M$. vitrata.

\section{Discussion}

Larval age

The parasitoid wasp, A. taragamae was not able to parasitize larvae older than three days (an age corresponding to the early second $M$. vitrata larval development stage). Indeed, larvae ran faster and 
Table 3 Development time (mean \pm SE), longevity (mean \pm SE), lifetime fecundity (mean \pm SE), daily fecundity (mean \pm SE), immature stage survivorship (mean $\pm \mathrm{SE}$ ) and sex ratio of Maruca vitrata at five different temperatures

\begin{tabular}{|c|c|c|c|c|c|}
\hline \multirow[t]{2}{*}{ Parameters } & \multicolumn{5}{|c|}{ Temperatures regimes } \\
\hline & $20^{\circ} \mathrm{C}$ & $24^{\circ} \mathrm{C}$ & $26^{\circ} \mathrm{C}$ & $28^{\circ} \mathrm{C}$ & $30^{\circ} \mathrm{C}$ \\
\hline \multicolumn{6}{|l|}{ Development time (days) } \\
\hline Egg-pupa & $20.6 \pm 0.60(75) \mathrm{a}$ & $\begin{array}{l}14.9 \pm 0.08 \\
\quad(70) \mathrm{b}\end{array}$ & $\begin{array}{l}12.5 \pm 0.06 \\
(100) \mathrm{c}\end{array}$ & $\begin{array}{l}11.2 \pm 0.07 \\
\quad(82) \mathrm{d}\end{array}$ & $\begin{array}{l}11.0 \pm 0.12 \\
\quad(81) \mathrm{d}\end{array}$ \\
\hline Pupa-adult & $15.5 \pm 0.06(71) \mathrm{a}$ & $8.5 \pm 0.06(67) b$ & $7.1 \pm 0.07(68) \mathrm{c}$ & $5.9 \pm 0.13(62) \mathrm{d}$ & $5.1 \pm 0.07(67) \mathrm{e}$ \\
\hline Egg-adult & $39.0 \pm 0.10(71) a$ & $\begin{array}{l}26.4 \pm 0.77 \\
(67) b\end{array}$ & $\begin{array}{l}22.8 \pm 0.66 \\
(68) \mathrm{c}\end{array}$ & $\begin{array}{l}20.2 \pm 0.18 \\
\quad(62) \mathrm{d}\end{array}$ & $\begin{array}{l}19.2 \pm 0.11 \\
(67) \mathrm{e}\end{array}$ \\
\hline \multicolumn{6}{|l|}{ Development cycle (days) } \\
\hline Male & $\begin{array}{l}38.9 \pm 0.14 \\
\quad(41) \mathrm{a} \alpha\end{array}$ & $\begin{array}{l}26.4 \pm 0.10 \\
\quad(34) \mathrm{b} \alpha\end{array}$ & $\begin{array}{l}20.7 \pm 0.18 \\
\quad(38) \mathrm{c} \alpha\end{array}$ & $\begin{array}{l}20.2 \pm 0.17 \\
(31) \mathrm{c} \alpha\end{array}$ & $\begin{array}{l}19.4 \pm 0.17 \\
\quad(32) \mathrm{d} \alpha\end{array}$ \\
\hline Female & $\begin{array}{l}39.1 \pm 0.21 \\
\quad(29) \mathrm{a} \alpha\end{array}$ & $\begin{array}{l}26.4 \pm 0.12 \\
\quad(31) \mathrm{b} \alpha\end{array}$ & $\begin{array}{l}22.7 \pm 0.12 \\
\quad(31) \mathrm{b} \beta\end{array}$ & $\begin{array}{l}20.1 \pm 0.31 \\
\quad(32) \mathrm{d} \alpha\end{array}$ & $\begin{array}{l}19.0 \pm 0.08 \\
\quad(35) \mathrm{e} \alpha\end{array}$ \\
\hline \multicolumn{6}{|l|}{ Longevity (days) } \\
\hline Male & $22.4 \pm 1.3(30) \mathrm{a} \alpha$ & $\begin{array}{l}12.5 \pm 0.71 \\
(30) \mathrm{b} \alpha\end{array}$ & $\begin{array}{l}12.9 \pm 1.0 \\
(30) \mathrm{b} \alpha\end{array}$ & $\begin{array}{l}7.9 \pm 0.81 \\
\quad(30) \mathrm{c} \alpha\end{array}$ & $\begin{array}{l}7.7 \pm 0.71 \\
\quad(30) \mathrm{c} \alpha\end{array}$ \\
\hline Female & $16.8 \pm 1.6(30) \mathrm{a} \beta$ & $\begin{array}{l}14.4 \pm 1.5 \\
(30) \mathrm{ab} \alpha\end{array}$ & $\begin{array}{l}12.0 \pm 1.1 \\
(30) \mathrm{b} \alpha\end{array}$ & $\begin{array}{l}10.4 \pm 0.94 \\
\quad(30) \mathrm{b} \beta\end{array}$ & $\begin{array}{l}5.4 \pm 0.83 \\
\quad(30) \mathrm{c} \beta\end{array}$ \\
\hline Lifetime fecundity (eggs/female) & $\begin{array}{l}121.5 \pm 16.6 \\
(30) \mathrm{ac}\end{array}$ & $\begin{array}{l}140.7 \pm 24.6 \\
(30) \mathrm{a}\end{array}$ & $\begin{array}{l}246.4 \pm 28.5 \\
\quad(30) \mathrm{b}\end{array}$ & $\begin{array}{l}145.0 \pm 27.2 \\
(30) \mathrm{a}\end{array}$ & $\begin{array}{l}46.7 \pm 15.6 \\
(30) \mathrm{c}\end{array}$ \\
\hline Daily fecundity eggs/female/day) & $8.0 \pm 1.2(30) \mathrm{ac}$ & $8.3 \pm 1.3(30) \mathrm{a}$ & $19.4 \pm 1.8(30) \mathrm{b}$ & $10.7 \pm 1.8(30) \mathrm{a}$ & $4.7 \pm 1.4(30) \mathrm{c}$ \\
\hline $\begin{array}{l}\text { Survival rate of larvae and cocoons } \\
(\%)\end{array}$ & $83.0 \pm 1.5(3) \mathrm{a}$ & $77.3 \pm 1.8(3) b$ & $77.0 \pm 0.0(3) b$ & $70.3 \pm 1.3(3) \mathrm{c}$ & $62.7 \pm 0.67(3) \mathrm{d}$ \\
\hline Sex ratio (\% females progeny) & 47.7a n.s. & 47.a n.s. & 46.3a n.s. & 47.0a n.s. & 47.3a n.s. \\
\hline
\end{tabular}

Numbers in parentheses are the number of repetitions

Means within each row followed by the same letters were not significantly different with Tukey test at 5\% following ANOVA for comparison between temperatures

Means within each column (same temperature) followed by Greek letters were not significantly different with $t$-paired test at $5 \%$ for comparison between male and female

For sex ratio, female proportions followed by the same letter were not significantly different with $\chi^{2}$ at $5 \%$ (based on $2 \times 5$ contingency table) for comparison between temperatures

n.s. indicates no difference $\left(P>0.05, \chi^{2}\right)$ between observed and expected $(50 \%)$ percentages of females at the same temperature

escaped from parasitism, suggesting a defensive behaviour (Brodeur et al. 1998). Moreover, older larvae may not be suitable for the wasp's development (Jones 1982; Brodeur and Boivin 2004).

Parasitism success on one-day-old larvae was the lowest. This was associated with low immature survival, which may be due to limited nutritional resources available in such early instar larvae (Arthur and Wylie 1959; Harvey et al. 2004). Hence, the parasitoid took longer to complete its development on one-day-old larvae (Table 1). The host size at oviposition was reported to affect the development duration of koinobiont parasitoids (Colinet et al. 2005). Although their hosts continue to grow after parasitism, such parasitoids were found to be selective regarding the host size or age at oviposition, which influence many of their other biological features (Jones 1982; Brodeur and Boivin 2004).

Sex allocation in many parasitoids species was found to be influenced by host age or size at oviposition (Arthur and Wylie 1959; Jones 1982; King 1987). Female wasps were reported to be selective as to the sex of the offspring they deposit in the host (Dicke 1999). Male offspring are often deposited in small hosts while female offspring are oviposited in larger hosts (Jones 1982; Dicke 1999). In our study, A. taragamae also exhibited this feature of host-size dependent sex allocation. Only male 
Table 4 Life table parameters (mean \pm SE) of Apanteles taragamae and its host Maruca vitrata at five different temperatures

\begin{tabular}{|c|c|c|c|c|c|}
\hline \multirow[t]{2}{*}{ Parameters } & \multicolumn{5}{|c|}{ Jackknife estimation } \\
\hline & $20^{\circ} \mathrm{C}$ & $24^{\circ} \mathrm{C}$ & $26^{\circ} \mathrm{C}$ & $28^{\circ} \mathrm{C}$ & $30^{\circ} \mathrm{C}$ \\
\hline \multicolumn{6}{|c|}{ Intrinsic rate of increase $\left(r_{m}\right)$ (females/female/day) } \\
\hline Apanteles taragamae & $0.14 \pm 0.001 \mathrm{a}$ & $0.23 \pm 0.01 b$ & $0.23 \pm 0.004 b$ & $0.24 \pm 0.01 b$ & $0.10 \pm 0.003 \mathrm{c}$ \\
\hline Maruca vitrata & $0.10 \pm 0.01 \mathrm{a}$ & $0.14 \pm 0.01 \mathrm{a}$ & $0.19 \pm 0.002 b$ & $0.20 \pm 0.01 b$ & $0.19 \pm 0.01 b$ \\
\hline \multicolumn{6}{|c|}{ Net reproduction rate $\left(R_{0}\right)$ (females/female) } \\
\hline Apanteles taragamae & $37.02 \pm 0.46 \mathrm{a}$ & $23.4 \pm 2.40 \mathrm{~b}$ & $24.5 \pm 1.5 b$ & $14.3 \pm 0.47 \mathrm{c}$ & $2.6 \pm 0.10 \mathrm{c}$ \\
\hline Maruca vitrata & $139.5 \pm 50.1 \mathrm{a}$ & $96.1 \pm 37.8 \mathrm{a}$ & $168.3 \pm 17.1 \mathrm{a}$ & $89.0 \pm 13.4 \mathrm{a}$ & $56.3 \pm 16.3 \mathrm{a}$ \\
\hline \multicolumn{6}{|c|}{ Mean generation time $(T)$ (day) } \\
\hline Apanteles taragamae & $26.2 \pm 0.14 \mathrm{a}$ & $13.9 \pm 0.04 b$ & $14.1 \pm 0.42 b$ & $10.9 \pm 0.21 \mathrm{c}$ & $10.6 \pm 0.60 \mathrm{c}$ \\
\hline Maruca vitrata & $47.5 \pm 2.02 \mathrm{a}$ & $32.3 \pm 2.07 b$ & $27.03 \pm 0.6 b c$ & $23.2 \pm 0.44 \mathrm{c}$ & $22.4 \pm 1.6 \mathrm{c}$ \\
\hline \multicolumn{6}{|l|}{ Doubling time (DT) (day) } \\
\hline Apanteles taragamae & $5.03 \pm 0.05 \mathrm{a}$ & $3.1 \pm 0.087 \mathrm{a}$ & $3.03 \pm 0.06 \mathrm{a}$ & $2.8 \pm 0.08 \mathrm{a}$ & $3.7 \pm 1.1 \mathrm{a}$ \\
\hline Maruca vitrata & $6.7 \pm 0.31 \mathrm{a}$ & $5.06 \pm 0.35 b$ & $3.7 \pm 0.03 \mathrm{c}$ & $3.6 \pm 0.15 \mathrm{c}$ & $3.6 \pm 0.19 \mathrm{c}$ \\
\hline \multicolumn{6}{|c|}{ Finite rate of increase $(\lambda)$ (females/female/day) } \\
\hline Apanteles taragamae & $1.2 \pm 0.001 \mathrm{a}$ & $1.3 \pm 0.01 b$ & $1.3 \pm 0.01 b$ & $1.3 \pm 0.01 b$ & $1.1 \pm 0.004 \mathrm{c}$ \\
\hline Maruca vitrata & $1.1 \pm 0.01 \mathrm{a}$ & $1.2 \pm 0.01 \mathrm{a}$ & $1.2 \pm 0.002 b$ & $1.2 \pm 0.01 \mathrm{~b}$ & $1.2 \pm 0.01 \mathrm{~b}$ \\
\hline
\end{tabular}

Means are means of three cohorts of ten females (in total 30) used to calculate life table parameters

Means within each row followed by the same letters were not significantly different with Tukey test at $5 \%$ following ANOVA for the same insect species

Table 5 Estimated parameters $( \pm \mathrm{SE})$ of four temperature-dependent models describing the influence of temperature on the intrinsic rate of increase and the developmental rate of Apanteles taragamae and its host Maruca vitrata

\begin{tabular}{|c|c|c|c|c|c|}
\hline \multirow[t]{2}{*}{ Model type } & \multirow[t]{2}{*}{ Parameters } & \multicolumn{2}{|l|}{ Apanteles taragamae } & \multicolumn{2}{|l|}{ Maruca vitrata } \\
\hline & & Intrinsic rate of increase & Developmental rate & Intrinsic rate of increase & Developmental rate \\
\hline \multirow[t]{6}{*}{ Linear regression } & Probability & 0.06 n.s. & 0.006 & 0.04 & 0.0008 \\
\hline & $a$ & - & $-0.08 \pm 0.02$ & $-0.15 \pm 0.06$ & $-0.03 \pm 0.005$ \\
\hline & $b$ & - & $0.006 \pm 0.001$ & $0.01 \pm 0.003$ & $0.003 \pm 0.0002$ \\
\hline & $K$ & - & 157 degree-days & - & 366.3 degree-days \\
\hline & $R^{2}$ & - & 0.94 & 0.92 & 0.98 \\
\hline & RSS & - & $1.4 \times 10^{-4}$ & $4.7 \times 10^{-4}$ & $6.6 \times 10^{-6}$ \\
\hline \multirow[t]{7}{*}{ Briére 1} & Probability & 0.004 & 0.002 & 0.006 & 0.0001 \\
\hline & $a$ & $0.0004 \pm 0.00005$ & $0.0001 \pm 0.000$ & $0.00002 \pm 0.000$ & $0.00003 \pm 0.000$ \\
\hline & $T_{0}$ & $14.9 \pm 1.2$ & $14.6 \pm 1.6$ & $13.7 \pm 2.9$ & $10.5 \pm 0.91$ \\
\hline & $T_{\max }$ & $30.2 \pm 0.1$ & $35.1 \pm 2.1$ & $33.1 \pm 1.7$ & $38.1 \pm 1.1$ \\
\hline & $R^{2}$ & 0.97 & 0.98 & 0.91 & 0.99 \\
\hline & RSS & $5.4 \times 10^{-4}$ & $5.3 \times 10^{-5}$ & $5.7 \times 10^{-4}$ & $6.6 \times 10^{-7}$ \\
\hline & & & - & - & - \\
\hline
\end{tabular}

n.s. Indicates that the model was not globally significant

- Indicates that parameters were not determined because the model was not globally significant

offspring emerged from one-day-old parasitized larvae (Table 1). However, female parasitoids may have oviposited eggs of both sexes in one-day-old larvae, whereas larvae of this age may not provide sufficient nutritional resources for female offspring to complete their development. Indeed, female offspring 


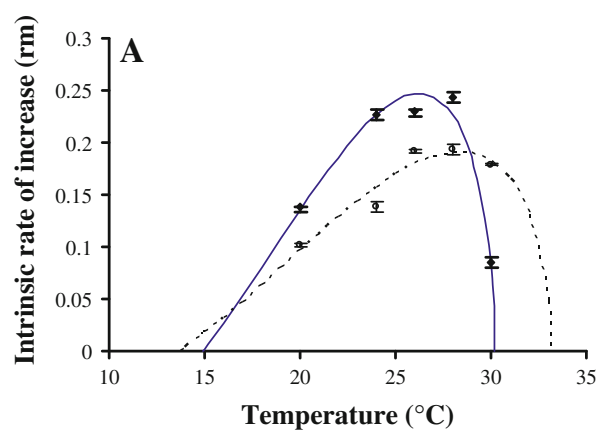

Fig. 2 Relationship between the temperature and the intrinsic rate of increase (A) or the developmental rate (B) of Apanteles taragamae and its host Maruca vitrata (mean $\pm \mathrm{SE}$ ) as

were reported to require more nutritional resources to complete their development compared to male offspring (Colinet et al. 2005). Thus, female offspring might suffer higher mortality so that only males emerged from the youngest larvae (Jones 1982; Brodeur and Boivin 2004). In contrast, in larger hosts, i.e. two- or three-day-old larvae in our study, both male and female offspring successfully developed as found by others (Jones 1982; Ueno 1999; Wang et al. 2008). When supplied with only large hosts, female wasps may control their offspring sex at oviposition by depositing unfertilized eggs that give rise to sons and fertilized eggs that give rise to daughters (Henter 2004). However, not all parasitoid species exhibit a host-size dependent sex allocation (Donaldson and Walter 1984). For instance, host size did not influence sex allocation in the parasitoid wasp Spalangia endius Walker (Hymenoptera: Pteromalidae) (Donaldson and Walter 1984; Napoleon and King 1999).

Comparison of males' longevity between three larval ages revealed that male wasps emerging from one-day-old parasitized larvae lived longest. This observation could be explained by differences in mating status. Mating can affect male fitness in terms of longevity (Dewsbury 1982; Onagbola et al. 2007). In fact, males and females emerging from two- or three-day-old parasitized larvae were coupled to study female fecundity, while males that emerged from one-day-old parasitized larvae remained unmated. Similar results were reported for Anagyrus kamali Moursi by Sagarra et al. (2002).

The proportion of female wasps that emerged from larvae parasitized at the age of two days was higher than that obtained in the experiments on the influence of temperature (Tables 1 and 2). This difference may

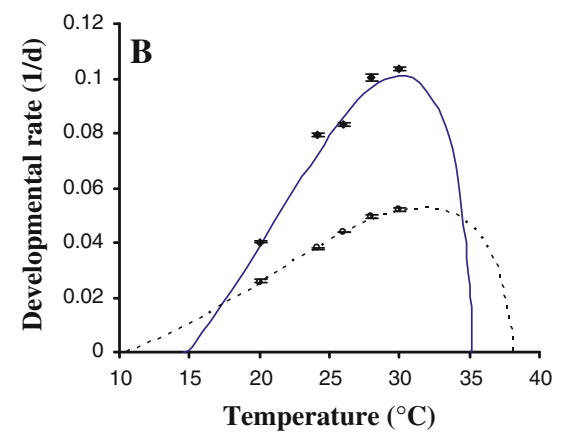

described by the Brière 1 model. Dashed line represents M. vitrata and continuous line represents A. taragamae

be due to the mating status of female wasps involved in the two experiments. In the experiment on suitability of larval age, female wasps were allowed to mate $48 \mathrm{~h}$ prior to being allowed to parasitize, while in the experiment on temperature effects, female wasps at the day of emergence were allowed to mate, and parasitize immediately after. In the last case, the first eggs laid by these females may not be fertilized giving then only male progeny which would increase the proportion of males.

The fact that no differences were obtained between the two larval ages (two- and three-day-old larvae) for the rate of parasitization and the lifetime fecundity supports the existence of a host size threshold (Jones 1982; Brodeur and Boivin 2004) for the normal development of A. taragamae.

Host size may also affect the size of the emerging wasp (Dicke 1999; Lacoume et al. 2006). Both male and female wasps are larger when they develop in larger hosts (Lacoume et al. 2006). Many studies show a relationship between parasitoid size and its fitness in terms of female reproductive capacity (lifetime fecundity) and longevity (Visser 1994; Ueno 1999; Lacoume et al. 2006; Thorne et al. 2006; Wang et al. 2008). However, contrary to these findings females or males of $A$. taragamae that emerged from larvae parasitized at the age of two or three days did not significantly differ in their fecundity or longevity (Table 1).

Host density

The percentage parasitism of $M$. vitrata larvae by A. taragamae increased with density, which is a good indicator of the performance of a biological control 
agent. A natural enemy that responds positively to an increase in pest population density is considered as a good candidate (Stiling 1987; Luna et al. 2007). If the parasitization rate increases with host density, this may contribute to host population regulation and to the system's stability (Walde and Murdoch 1988). The underlying mechanisms of accelerating functional responses include decreased host handling time, increased host searching rate and egg availability (Stiling 1987; Walde and Murdoch 1988). Efficiency of host searching by a parasitoid depends on its ability to use infochemicals from its host and host plants (Vet and Dicke 1992). In this process, learning may play a determinant role. Our observations demonstrate the ability of A. taragamae to respond positively to an increasing population of M. vitrata. However, this functional response was obtained with a simplified experimental arena and may be different in a more complex environment (i.e. field conditions). Even in the laboratory, the functional response of a parasitoid is affected by many factors such as size of experimental arena, tested densities, time duration of experiments, distribution of hosts, the possibility of searching parasitoids to leave the experimental units and number of parasitoids searching together (Islam et al. 2006). Moreover, the foraging behaviour under field conditions is determined by many other factors namely host patch accessibility or distribution, presence of competitors and temperature (Fernández-arhex and Corley 2003; Luna et al. 2007). In the present work, all female parasitoids escaped the experimental units through holes made for this purpose a few minutes after release, without parasitizing host larvae. Because subsequent experiments did not include this possibility, we would have expected high parasitism levels at lower density since the wasps had the possibility to revisit host larvae. Consequently, we would also have expected that the percentage parasitism would decrease with host density, but this was not the case, as the percentage parasitism increased with increasing host density. Such laboratory findings are useful for assessing the performance of A. taragamae as a biological control agent.

\section{Temperature}

Apanteles taragamae and its host $M$. vitrata successfully developed under a range of temperatures. Linear regressions indicated significant negative correlations between the temperature and most of the life history parameters measured on both insect species. However, the relationship between the temperature and the intrinsic rate of increase $\left(r_{m}\right)$ or the developmental rate is generally sigmoidal (Campbell et al. 1974; Brière et al. 1999). This thermal pattern is characteristic of poikilotherm species like insects which are not able to regulate their body temperature in response to the increase in environment temperature (Howe 1967; Ivanović et al. 1992). Above the upper threshold, temperature affects enzyme activity or nutrient metabolism (Langridge 1963; Sharpe and DeMichele 1977), leading to death and rapid decline of the insect population (Ivanovic et al. 1992).

The Brière 1 model estimates quite well the lower thermal threshold for the parasitoid development but not the upper one, when compared to the values reported by Adati et al. (2004) on M. vitrata, which ceased to develop below $10.4-11.7^{\circ} \mathrm{C}$ and above $31.9^{\circ} \mathrm{C}$. It also fits well to estimate the lower thermal threshold but not the optimum temperature and the upper thermal threshold of $M$. vitrata.

Comparison between the intrinsic rate of natural increase of $A$. taragamae and that of its host $M$. vitrata revealed that the parasitoid reproduced significantly faster than did its host at all the tested temperatures with the exception of $30^{\circ} \mathrm{C}$. The maximum intrinsic rate of natural increase ( 0.24 female/ female/day) was obtained for A. taragamae against 0.19 for the host at $28^{\circ} \mathrm{C}$. The highest $r_{m}$ obtained for the moth is closer to that $(0.18$ female/female/day $)$ found by Chi et al. (2005) at $27^{\circ} \mathrm{C}$. In Benin, the mean temperature over the last 30 years did not exceed $28^{\circ} \mathrm{C}$ (Emert and Brücher 2008). Minima average $22.6^{\circ} \mathrm{C}$ in South Benin and $20.8^{\circ} \mathrm{C}$ in the Northern part of Benin, while maxima averaging $32.5^{\circ} \mathrm{C}$ in the South, reach $34.3^{\circ} \mathrm{C}$ in the North during the long dry season. If we assume that the mean temperature is around $30^{\circ} \mathrm{C}$ during the dry season which lasts three months, the wasp would have eight generations against four generations for its host during this season. The wasp would accomplish 25 generations against 12 for its host during the remaining nine months, assuming the mean temperature to be $28^{\circ} \mathrm{C}$. The overall annual increase in the parasitoid population would be 75 females per female against 72 females per female for the host. These findings suggest that $A$. taragamae is likely to exert 
effective biological control of $M$. vitrata once released and established in Benin agro-ecosystems.

The present study provides basic information on the influence of larval host age, density and temperature on some biological parameters of A. taragamae exploiting its host $M$. vitrata, and is an essential step in the development of biological control approaches (Lane et al. 1999; van Lenteren et al. 2003) against this crambid pest.

Acknowledgments We greatly thank the Netherlands Universities' Foundation for International Cooperation (NUFFIC) for financially supporting this work through the Netherlands Fellowship Programmes (NFP). We also thank Mr. Cyriaque Agboton, Mathias Azokpota, Pascal Agountchémè and Judith Glèlè for assistance at the Laboratory of cowpea section of the International Institute of Tropical Agriculture (IITA), Benin Station. The comments by two anonymous reviewers were helpful in improving the manuscript.

Open Access This article is distributed under the terms of the Creative Commons Attribution Noncommercial License which permits any noncommercial use, distribution, and reproduction in any medium, provided the original author(s) and source are credited.

\section{References}

Adati T, Nakamura S, Tamò M, Kawazu K (2004) Effect of temperature on development and survival of the legume pod borer, Maruca vitrata (Fabricius) (Lepidoptera: Pyralidae) reared on a semi-synthetic diet. Appl Entomol Zool 39(1):139-145

Arodokoun DY, Tamò M, Cloutier C, Adeoti R (2003) Importance of alternative host plants for the annual cycle of the legume pod borer, Maruca vitrata Fabricius (Lepidoptera: Pyralidae) in Southern and Central Benin. Insect Sci Appl 23(2):103-113

Arthur AP, Wylie HG (1959) Effects of host size on sex ratio, development time and size of Pimpla turionellae (L.) (Hymenoptera: Ichneumonidae). Entomophaga 4:297-301

Birch LC (1948) The intrinsic rate of natural increase of an insect population. J Anim Ecol 17(1):15-26

Bottenberg H, Tamò M, Arodokoun D, Jackai LEN, Singh BB, Youm O (1997) Population dynamics and migration of cowpea pests in northern Nigeria: implications for integrated pest management. In: Singh BB, Mohan Raj DR, Dashiell KE, Jackai LEN (eds) Advances in cowpea research. International Institute of Tropical Agriculture and Japan International Center for Agricultural Sciences, IITA, Ibadan, pp 271-284

Brière JF, Pracros P, Le Roux AY, Pierre JS (1999) A novel rate model of temperature-dependent development for arthropods. Environ Entomol 28(1):22-29

Brodeur J, Boivin G (2004) Functional ecology of immature parasitoids. Annu Rev Entomol 49:27-49
Brodeur J, Geervliet JBF, Vet LEM (1998) Effect of Pieris host species on life history parameters in solitary specialist and gregarious generalist parasitoids (Cotesia species). Entomol Exp Appl 86:145-152

Campbell A, Frazer BD, Gilbert N, Gutierrez AP, Mackauer M (1974) Temperature requirements of some Aphids and their parasites. J Appl Ecol 11(2):431-438

Chi Y, Sakamaki Y, Tsuda K, Kusigemati K (2005) Effect of temperature on oviposition and adult longevity of the legume pod borer, Maruca vitrata (Fabricius) (Lepidoptera: Crambidae). Jpn J Appl Entomol Zool 49:29-32

Cloutier C, Duperron J, Tertuliano M, McNeil JN (2000) Host instar body size and fitness in the koinobiotic parasitoid Aphidius nigripes. Entomol Exp Appl 97:29-40

Colinet H, Salin C, Boivin G, Hance Th (2005) Host age and fitness-related traits in a koinobiont aphid parasitoid. Ecol Entomol 30:473-479

Dewsbury DA (1982) Ejaculate cost and male choice. Am Nat 119(5):601-610

Dicke M (1999) Direct and indirect effects of plants on the performance of beneficial organisms. In: Ruberson JR (ed) Handbook of pest management. Marcel Dekker, New York, pp 105-153

Donaldson JS, Walter GH (1984) Sex-ratios of Spalangia endius (Hymenoptera: Pteromalidae), in relation to current theory. Ecol Entomol 9(4):395-402

Ekesi S (1999) Insecticide resistance in filed populations of the legume pod borer Maruca vitrata Fabricius (Lepidoptera: Pyralidae), on cowpea, Vigna unguiculata (L.) Walp. In Nigeria. Int J Pest Manag 45(1):57-59

Emert V, Brücher T (2008) The climate of Benin (1961 to 1990). In: Judex M, Thamm HP (eds) IMPETUS Atlas Benin. Research Results 2000-2007, 3rd edn. Department of Geography, University of Bonn, Germany, pp 17-18

Fernández-arhex V, Corley JC (2003) The functional response of parasitoids and its implications for biological control. Biocontrol Sci Tech 13(4):403-413

Harbison JL, Legaspi JC, Fabritius SL, Sadan RR, Legaspi BC, Enkegaard A (2001) Effects of age and host number on reproductive biology of Allorhogas pyralophagus (Hymenoptera: Braconidae) attacking the Mexican rice borer (Lepidoptera: Pyralidae). Environ Entomol 30(1): 129-135

Harvey JA (2005) Factors affecting the evolution of development strategies in parasitoid wasps: the importance of functional constraints and incorporating complexity. Entomol Exp Appl 117:1-13

Harvey JA, Bezember TM, Elzinga JA, Strand MR (2004) Development of the solitary endoparasitoid Microplitis demolitor: host quality does not increase with host age and size. Ecol Entomol 29:35-43

Henter HJ (2004) Constrained sex allocation in a parasitoid due to variation in male quality. J Evol Biol 17:886-896

Holling CS (1959) The components of predation as revealed by a study of small-mammal predation of the European pine sawfly. Can Entomol 91:293-320

Howe RW (1967) Temperature effects on embryonic development in insects. Annu Rev Entomol 12:15-42

Huang CC, Peng WK, Talekar NS (2003) Parasitoids and other natural enemies of Maruca vitrata feeding on Sesbania cannabina in Taiwan. BioControl 48(4):407-416 
Hulting FL, Orr DB, Obrycki JJ (1990) A computer program for calculation and statistical comparison of intrinsic rate of increase and associated life table parameters. Fla Entomol 73(4):601-612

Islam N, Islam W, Mondal K (2006) Functional response of Dinarmus basalis (Rond.) (Hymenoptera: Pteromalidae) parasitizing Callosobruchus maculates (F). J Bio-Sci 14:11-16

Ivanović J, Janković-Hladni M, Djordjević S, Stamenović S, Lazarević J (1992) The effect of high temperature on metabolism of Morzmus funereus larvae during an intermoult period. J Insect Physiol 38(11):877-883

Jackai LEN, Raulston JR (1988) Rearing the legume pod borer, Maruca testulalis Geyer (Lepidoptera: Pyralidae) on artificial diet. Trop Pest Manag 34(2):168-172

Jones WT (1982) Sex ratio and host size in parasitoid wasp. Behav Ecol Sociobiol 10:207-210

Kalyebi A, Overholt WA, Schulthess F, Mueke JM, Sithanantham S (2006) The effect of temperature and humidity on the bionomics of six African egg parasitoids (Hymenoptera: Trichogrammatidae). Bull Entomol Res 96: 305-314

Kamara AY, Chikoye D, Omoigui LO, Dugje IY (2007) Influence of insecticide spraying regimes and cultivar on insect pests and yield of cowpea in the dry savannas of north-eastern Nigeria. J Food, Agric \& Environ 5(1): $154-158$

King BH (1987) Offsprings sex ratios in parasitoid wasps. Quart Rev Biol 62(4):367-396

Kontodimas DC, Eliopoulos PA, Stathas GJ, Economou LP (2004) Comparative temperature-dependent development of Nephus includens (Kirsch) and Nephus bisignatus (Boheman) (Coleoptera: Coccinelidae) preying on Planococcus citri (Risso) (Homptera: Pseudococcidae): evaluation of a linear and various nonlinear models using specific criteria. Environ Entomol 33(1):1-11

Lacoume S, Bressac C, Chrevrier C (2006) Effect of host size on male fitness in the parasitoid wasp Dinarmus basalis. J Insect Physiol 52:249-254

Lane SD, Mills NJ, Getz WM (1999) The effect of parasitoid fecundity and host taxon on the biological control of insect pests: the relationship between theory and data. Ecol Entomol 24:181-190

Langridge J (1963) Biochemical aspects of temperature response. Annu Rev Entomol 14:441-462

Luna MAG, Nchez NESA, Pereyra P (2007) Parasitism of Tuta absoluta (Lepidoptera, Gelechiidae) by Pseudapanteles dignus (Hymenoptera, Braconidae) under laboratory conditions. Environ Entomol 34(4):887-893

Maia AHN, Luiz AJB, Campanhola C (2000) Statistical inference on associated fertility life table parameters using Jackknife technique: computational aspects. J Econ Entomol 93(2):511-518

Marquardt DW (1963) An algorithm for least squares estimation of nonlinear parameters. J Soc Ind \& Appl Math 11(2):431-441

Mohan C, Sathiamma B (2007) Potential for lab rearing of Apanteles taragamae the larval endoparasitoid of coconut pest Opisina arenosella, on the rice moth Corcyra cephalonica. BioControl 52(6):747-752
Nampala P, Ogenga-latigo MW, Kyamanywa S, Adipala E, Oyodo M, Jackai LEN (2002) Potential impact of intercropping on major cowpea field pests in Uganda. Afri Crop Sci J 10(4):335-344

Napoleon ME, King BH (1999) Offspring sex ratio response to host size in the parasitoid wasp Spalangia endius. Behav Ecol Sociobiol 46:325-332

Onagbola EO, Fadamiro HY, Mbata GN (2007) Longevity, fecundity, and progeny sex ratio of Pteromalus cerealellae in relation to diet, host provision and mating. Biol Control 40:222-229

Pennacchio F, Strand MR (2006) Evolution of developmental strategies in parasitic Hymenoptera. Annu Rev Entomol 51:233-258

Peter C, David BV (1990) Influence of host plants on the parasitism of Diaphania indica (Lepidoptera: Pyralidae) by Apanteles taragamae Viereck (Hymenoptera: Braconidae). Insect Sci Appl 11:903-906

Roy M, Brodeur J, Cloutier C (2002) Relationship between temperature and development rate of Stehorus punctillum (Coleoptera: Coccinellidae) and its prey tetranychus mcdanieli (Acarina: Tetranychidae). Environ Entomol 31(1):177-187

Sagarra LA, Vincent C, Stewart RK (2002) Impact of mating on Anagyrus kamli Moursi (Hym. Encyrtidae) lifetime fecundity, reproductive longevity, progeny emergence and sex ratio. J Appl Entomol 126:400-404

Sharma HC (1998) Bionomics, host plant resistance, and management of the legume pod borer, Maruca vitrata-a review. Crop Prot 17:373-386

Sharpe PJH, DeMichele DW (1977) Reaction kinetics of poikilotherm development. J Theor Biol 64:649-670

Stiling PD (1987) The frequency of density dependency in insect host-parasitoid systems. Ecology 68(4):844-856

Tamò M, Bottenberg H, Arodokoun DY, Adeoti R (1997) The feasibility of classical biological control of two major cowpea insect pests pp 259-270. In: Singh BB, Mohan Raj DR, Dashiell KE, Jackai LEN (eds) Advances in cowpea research. Copublication of International Institute of Tropical Agriculture (IITA) and Japan International Center for Agricultural Sciences (JIRCAS), IITA, Ibadan

Taylor TA (1978) Maruca testulalis, an important pest of tropical grain legumes: pp. 193-200. In: Singh SR, van Emden HF, Taylor TA (eds) Pests of grain legumes: ecology and control. London, Academic press

Taylor F (1981) Ecology and evolution of physiology time in insects. Am Nat 117(1):1-23

Thorne AD, Pexton JJ, Dytham C, Mayhew PJ (2006) Small body size in an insect shifts development, prior to adult eclosion, towards early reproduction. Proc R Soc B 273: 1099-1103

Uçkan F, Ergin E (2002) Effect of host diet on the immature development time, fecundity, sex ratio, adult longevity and size of Apanteles galleriae (Hymenoptera: Braconidae). Environ Entomol 31:168-171

Uçkan F, Ergin E (2003) Temperature and food source effects on adult longevity of Apanteles galleriae Wilkinson (Hymenoptera: Braconidae). Environ Entomol 32(3): 441-446 
Uçkan F, Ergin E, Ayaz F (2004) Modeling age- and densitystructured reproductive biology and seasonal survival of Apanteles galleriae Wilkinson (Hym., Braconidae). J Appl Entomol 128(6):407-413

Ueno T (1999) Host-size-dependent sex ratio in a parasitoid wasp. Res Popul Ecol 41:47-57

van Lenteren JC, Babendreier D, Bigler F, Burgio G, Hokkanen HMT, Kuske S, Loomans AJM, Menzler-Hokkanen I, Van Rijn PCJ, Thomas MB, Tommasini MG, Zeng QQ (2003) Environmental risk assessment of exotic natural enemies used in inundative biological control. BioControl 48:3-38

Vet LEM, Dicke M (1992) Ecology of infochemical use by natural enemies in a tritrophic context. Annu Rev Entomol 37:141-172
Visser ME (1994) The importance of being large: the relationship between size and fitness in females of the parasitoid Aphaereta minuta (Hymenoptera: Braconidae). J Anim Ecol 63(4):963-978

Walde SJ, Murdoch WW (1988) Spatial density dependence in parasitoids. Annu Rev Entomol 33:441-466

Wang XY, Yang ZQ, Wu H, Gould JR (2008) Effects of host size on the sex ratio, clutch size, and size of adult Spathius agrili, and ectoparasitoid of emerald ash borer. Biol Control 44:7-12

West SA, Flanagan KE, Godfray HCJ (1999) Sex allocation and clutch size in parasitoid wasps that produce single sex broods. Anim Behav 55:265-275 